\title{
Evaluation of Sweet Pepper (Capsicum annum L.) Varieties as Influnced by Nitrogen Levels in Chitwan, Nepal
}

\author{
Santosh Lohani ${ }^{1}$, Moha Dutta Sharma ${ }^{2}$, Shree Chandra Shah ${ }^{3}$ and Arjun Kumar Shrestha ${ }^{2}$ \\ ${ }^{1}$ Nepal Agricultural Research Council \\ ${ }^{2}$ Department of Horticulture, Agriculture and Forestry University \\ ${ }^{3}$ Department of Soil Science \& Agri-engineering, Agriculture and Forestry University \\ Corresponding author's email: lohanisantos@gmail.com
}

Received on: 15 July 2019, Revised on: 16 September 2019, Accepted on: 14 November 2019

\begin{abstract}
An experiment was conducted to assess the performance of sweet pepper varieties as influenced by nitrogen levels from August 2014 to February 2015 at Mangalpur, Chitwan. The experiment was laid out in two factorial Randomized Complete Block Design (RCBD) with three replications having sixteen treatments. Varieties and levels of nitrogen significantly affected growth, yield and qualitative parameters of fruits. Hybrid Indra and NS 632 performed better than open pollinated varieties viz. Sagar and California Wonder. Days to fifty percent flowering of NS 632 were earlier than California Wonder. Indra variety had the highest plant height $(52.18 \mathrm{~cm})$, number of secondary branches per plant (13.51) from $250 \mathrm{~kg}$ N/ha through chemical fertilizer while number of leaves per plant was higher in NS 632 variety (57.22) than Sagar variety (47.37). Indra variety showed the highest fruit weight $(87.59 \mathrm{~g})$ and total yield $(39.45 \mathrm{t} / \mathrm{ha})$ but NS 632 variety produced more number of fruits per plant (9.25) than California Wonder variety. This study showed that sweet pepper yield of hybrid varieties applied with $250 \mathrm{~kg} \mathrm{~N} /$ ha through chemical fertilizer was appropriate dose to get optimum yield under Chitwan condition.
\end{abstract}

Keywords: : Sweet pepper and Nitrogen

\section{Introduction}

Sweet pepper (Capsicum annum L. var. grossum Sendt.; $2 \mathrm{n}=2 \mathrm{x}=24$ ) is commonly known as sweet pepper, capsicum or green pepper. In Nepal, sweet pepper is growing in 1318 ha area with production of $14216 \mathrm{mt}$ and productivity of $10.8 \mathrm{t} / \mathrm{ha}$ (MoAD, 2014). Among capsicum growing areas of Nepal, Chitwan is the major Sweet pepper producing district with 114 ha area, 1362 $\mathrm{mt}$ production and productivity of $12 \mathrm{t} / \mathrm{ha}(\mathrm{MoAD}$, 2014). Nepal imports a huge amount of chilli and sweet peppers $(2859587 \mathrm{~kg}$ ) from India (MoAD, 2013).
Chilli cultivars greatly vary in ability to flowering, fruit set, yield potential and other quantitative attributes under different agro-climates (Rani, 1996 and Gupta, 2003). It is fact that, all varieties do not perform equally well in all areas. It is essential to know the performance of varieties in a specific area.

Capsicum requires heavy fertilization at early stage for optimum plant growth and higher yield. Nitrogen is an essential part of nucleic acids and chlorophyll molecules (Devlin, 1972). Use of organic manures alone cannot fulfill the crop nutrients requirement

Copyright (C) 2020 Nepal Horticulture Society. This article is licensed under Creative Commons Attribution 4.0 Internationa License. This permits unrestricted use, distribution and reproduction in any medium provided the original work is properly cited 
(Deore, Limaye, Shinde \& Laware, 2010). Bokhtiar, Paul, and Alam, (2008) reported that organic manures, when applied with chemical fertilizers gave better yield than individual ones. Therefore, use of the optimum level and combination of nutrients depend on the variety as well as location (Sharma \& Upadhaya, 1993). Growers are still facing problems in the use of chemical fertilizers, particularly nitrogenous fertilizer, for optimum production.

\section{Materials And Methods}

\section{Location of the sites}

The experiment was conducted in the farmer's field of Mangalpur, Chitwan (27040' N, 84019' E), Central Development Region, Nepal. It has a subtropical climate with an altitude of 228 meters above mean sea level and soil is alluvial deposited by Narayani and Rapti River.

\begin{tabular}{|l|l|l|}
\hline \multicolumn{2}{|c|}{ Table 1. Soil physico-chemical properties of the research site, Mangalpur, Chitwan, Nepal, 2014} \\
\hline \multicolumn{1}{|c|}{ Details } & \multicolumn{1}{|c|}{ Mean } & \multicolumn{1}{c|}{ Ratings } \\
\hline $\mathrm{pH}$ & 6.7 & Acidic \\
\hline Total nitrogen $(\%)$ & 0.13 & Medium \\
\hline Phosphorous $(\mathrm{kg} / \mathrm{ha})$ & 104.6 & High \\
\hline Potash $(\mathrm{kg} / \mathrm{ha})$ & 56.6 & Low \\
\hline Organic matter $(\%)$ & 2.5 & $\neg$ Medium \\
\hline Soil type & Sand $(75.3 \%)$, silt $(18 \%)$, clay $(6.7 \%)$ & Sandy loam \\
\hline
\end{tabular}

Source: Directorate of Soil Management, DOA, Harihar Bhawan, Lalitpur, Nepal.

\section{Experimental details}

The experiment was carried out from August, 2014 to March, 2015 with two factors factorial completely randomized block design (RCBD) with 16 treatment combinations and 3 replications. Four varieties (viz. California Wonder, Sagar, NS 632 and Indra) and four levels of $\mathrm{N}$ from different sources (viz. $200 \mathrm{~kg} \mathrm{~N} / \mathrm{ha}$ through chemical fertilizer, $200 \mathrm{~kg} \mathrm{~N} /$ ha through FYM,
$250 \mathrm{~kg} \mathrm{~N} / \mathrm{ha}$ through chemical fertilizer and $150 \mathrm{~kg} \mathrm{~N} /$ ha through chemical fertilizer) were used. The individual plot size was $2.5 \mathrm{~m} \times 2.4 \mathrm{~m}$. The row to row distance was $50 \mathrm{~cm}$ and plant to plant distance was $40 \mathrm{~cm}$. There were 5 rows in each plot and 6 plants per row. There were 30 plants in each plot and inner 6 plants were selected for taking observation. Thirty days old seedlings were transplanted on 22nd September, 2014.

\begin{tabular}{|c|c|c|c|c|}
\hline \\
\hline S.N & Varieties & Types & Source & Status \\
\hline & $\begin{array}{l}\text { Calofornia } \\
\text { Wonder }\end{array}$ & OP & $\begin{array}{l}\text { Global Seeds Pvt. Ltd, } \\
\text { Kathmandu, Nepal }\end{array}$ & $\begin{array}{l}\text { Released variety by Seed Quality Control } \\
\text { Center (SQCC),Nepal }\end{array}$ \\
\hline & Sagar & OP & Chia tai Co., Ltd., Thailand & Registered variety (SQCC, Nepal) \\
\hline & NS 632 & F1 & Namdhari Seeds, Pvt.Ltd, India & Registered variety (SQCC, Nepal) \\
\hline & Indra & F1 & Syngenta India Limited & Popular variety for Farmers (Non registered) \\
\hline
\end{tabular}

$\mathrm{F}^{1}=$ First generation hybrid and $\mathrm{OP}=$ Open pollinated varieties

\section{Treatments details}

\begin{tabular}{|l|l|l|}
\hline \multicolumn{3}{|c|}{ Table 2. Treatment combinations } \\
\hline Treatments & \multicolumn{1}{|c|}{ Combination } & Symbols \\
\hline T1 & California Wonder and $200 \mathrm{~kg} \mathrm{~N} /$ ha through chemical fertilizer & V1N1 \\
\hline T2 & California Wonder and $200 \mathrm{~kg} \mathrm{~N} /$ ha through FYM & V1N2 \\
\hline T3 & California Wonder and $250 \mathrm{~kg} \mathrm{~N} / \mathrm{ha}$ through chemical fertilizer & V1N3 \\
\hline T4 & California Wonder and $150 \mathrm{~kg} \mathrm{~N} / \mathrm{ha}$ through chemical fertilizer & V1N4 \\
\hline T5 & Sagar and $200 \mathrm{~kg} \mathrm{~N} / \mathrm{ha}$ through chemical fertilizer & V2N1 \\
\hline T6 & Sagar and $200 \mathrm{~kg} \mathrm{~N} / \mathrm{ha}$ through FYM & V2N2 \\
\hline
\end{tabular}




\begin{tabular}{|l|l|l|}
\hline T7 & Sagar and $250 \mathrm{~kg} \mathrm{~N} / \mathrm{ha}$ through chemical fertilizer & V2N3 \\
\hline T8 & Sagar and $150 \mathrm{~kg} \mathrm{~N} / \mathrm{ha}$ through chemical fertilizer & V2N4 \\
\hline T9 & NS 632 and $200 \mathrm{~kg} \mathrm{~N} /$ ha through chemical fertilizer & V3N1 \\
\hline T10 & NS 632 and $200 \mathrm{~kg} \mathrm{~N} / \mathrm{ha}$ through FYM & V3N2 \\
\hline T11 & NS 632 and $250 \mathrm{~kg} \mathrm{~N} / \mathrm{h}$ through chemical fertilizer & V3N3 \\
\hline T12 & NS 632 and $150 \mathrm{~kg} \mathrm{~N} /$ ha through chemical fertilizer & V3N4 \\
\hline T13 & Indra and $200 \mathrm{~kg} \mathrm{~N} / \mathrm{ha}$ through chemical fertilizer & V4N1 \\
\hline T14 & Indra and $200 \mathrm{~kg} \mathrm{~N} / \mathrm{ha}$ through FYM & V4N2 \\
\hline T15 & Indra and $250 \mathrm{~kg} \mathrm{~N} / \mathrm{ha}$ through chemical fertilizer & V4N3 \\
\hline T16 & Indra and $150 \mathrm{~kg} \mathrm{~N} /$ ha through chemical fertilizer & V4N4 \\
\hline
\end{tabular}

\section{Report of FYM test}

Table 3. Laboratory analysis of the farmyard manure (FYM) used in the experiments

\begin{tabular}{|l|l|l|l|l|}
\hline \multicolumn{1}{|c|}{ Description } & \multicolumn{1}{|c|}{$\begin{array}{c}\text { Total nitrogen } \\
(\% \text { on oven dry basis })\end{array}$} & $\begin{array}{c}\text { Total phosphorous } \\
(\% \text { on oven dry basis })\end{array}$ & $\begin{array}{c}\text { Total potash } \\
(\% \text { oven dry basis })\end{array}$ & Moisture (\%) \\
\hline Standard Quality & $>1.5$ & $>0.5$ & $>1.5$ & $\leq 30$ \\
\hline Criteria Lab results & 1.50 & 1.25 & 2.55 & 67.43 \\
\hline
\end{tabular}

Source: Soil Laboratory, Directorate of Soil Management, DOA, Harihar Bhawan, Lalitpur, Nepal

The quantity of organic manure was calculated based on nitrogen content of the organic manure tested in the laboratory (Table 3). The amount of organic manures to fulfill the required nitrogen was doubled assuming that only $50 \%$ of $\mathrm{N}$ would be available in the first season (Baldwin and Greenfield, 2006; Bary, Cogger and Sullivan, 2004).

Well decomposed farmyard manure (FYM) was obtained from the farmer's shed. Farmyard manure was applied @ 30 t/ha in all plots. Treatments having 200 $\mathrm{kg} \mathrm{N} / \mathrm{ha}$ through FYM was applied plus $80 \mathrm{t} / \mathrm{ha} \mathrm{FYM}$ in the plot. FYM was applied during third ploughing which is one week prior to planting of seedlings. Nitrogen was applied at the rate of 150,200 and 250 $\mathrm{kg} / \mathrm{ha}$ through Di-ammonium phosphate (DAP) and urea for the remaining treatments. The recommended dose of phosphorous $(100 \mathrm{~kg} / \mathrm{ha})$ was applied through DAP (46\% P2O5) . In FYM treated plots, phosphorous was supplied through single super phosphate $(16 \%$ $\mathrm{P} 2 \mathrm{O} 5)$. The recommended dose of potash $(100 \mathrm{~kg} /$ ha) was applied through Muriate of Potash (MOP). In each treatment, half dose of nitrogen, full dose of phosphorous and potash were incorporated into the soil at the time of transplanting. The remaining amount of nitrogen was splitted into three equal parts and each part was top-dressed at 25, 50 and 75 days after transplanting.

\section{Observations and measurements}

\section{Plant height}

Plant height was measured from the ground level to the growing tip.

\section{Number of leaves per plant}

Number of green, photosynthetically active leaves excluding senescent and emerging leaves per plant were counted.

\section{Number of primary and secondary branches per plant}

Primary branches and secondary branches were counted on selected 6 plants at 60 and 100 days after transplanting.

\section{Number of fruits per plant and Average fruit weight}

Harvested fruits from 12 observational plants of each plot were taken. For calculating mean fruit weight (g), the total weight of the fruits was divided by the total number of fruits picked from 12 observational plants in cropping period. Total number of fruits taken from 12 observational plants was divided by 12 to calculate Number of fruits per plant. 


\section{Fruit yield}

Thel fruit weight from all the pickings obtained from 12 observational plants of each treatment was summed up separately treatment wise and yield $(\mathrm{t} / \mathrm{h})$ was calculated based on the area covered by 12 observational plants.

\section{Results}

Effects of varieties and nitrogen levels on growth parameters

There was significant effect of varieties on plant height at all growth stages of the plant. At all growth stages, the highest plant height was recorded in variety Indra. At 100 DAT, variety Indra was the tallest $(52.18 \mathrm{~cm})$ (Table 4).

There was significant increment in the plant height from increasing levels of nitrogen from 150 to 250 $\mathrm{kg} \mathrm{N} / \mathrm{ha}$. At 100 DAT, the highest plant height (49.26 $\mathrm{cm}$ ) was attained with $250 \mathrm{~kg} \mathrm{~N} / \mathrm{ha}$ through chemical fertilizer and the lowest $(43.66 \mathrm{~cm})$ from $200 \mathrm{~kg} \mathrm{~N} /$ ha through FYM. The effects of $150 \mathrm{~kg} \mathrm{~N} / \mathrm{ha}$ through chemical fertilizer and $200 \mathrm{~kg} \mathrm{~N} / \mathrm{ha}$ through FYM were non-significant.

At 100 DAT, the highest number of leaves was from NS 632 (57.22) which was at par with Indra (55.03). The lowest was recorded in Sagar (47.37) which was statistically similar to California Wonder (48.68). Also at $100 \mathrm{DAT}$, the highest number of leaves per plant (58.56) was obtained from $250 \mathrm{~kg} \mathrm{~N} / \mathrm{ha}$ and the lowest (47.13) from $150 \mathrm{~kg} \mathrm{~N} / \mathrm{ha}$.

There were significant effect of varieties on plant height and number of secondary branches where as non-significant with number of primary branches at 100 DAT. The highest number of branches per plant was from Indra which was consistent with NS 632 followed by California Wonder and Sagar. At 100 DAT, the highest (12.62) number of secondary branches per plant was from $250 \mathrm{~kg} \mathrm{~N} / \mathrm{ha}$ and the lowest (11.81) was recorded from $150 \mathrm{~kg} \mathrm{~N} /$ ha through chemical fertilizer.

Table 4. Effects of varieties and nitrogen levels on plant height at different growth stages of sweet pepper at Mangalpur, Chitwan (2014/2015)

\begin{tabular}{|l|l|l|l|l|}
\hline \multicolumn{1}{|c|}{ Treatments } & \multicolumn{1}{|c|}{$\begin{array}{c}\text { Plant height } \\
\text { (cm) }\end{array}$} & $\begin{array}{c}\text { Number of } \\
\text { leaves per } \\
\text { plant }\end{array}$ & $\begin{array}{c}\text { Number of } \\
\text { Primary } \\
\text { branches }\end{array}$ & $\begin{array}{c}\text { Number of } \\
\text { secondary } \\
\text { branches }\end{array}$ \\
\hline & 100 DAT & 100 DAT & 100 DAT & $100 \mathrm{DAT}$ \\
\hline Varieties (Fa) & & & & \\
\hline V1(California Wonder) & $41.13 \mathrm{c}$ & $48.68 \mathrm{~b}$ & 3.40 & $11.72 \mathrm{bc}$ \\
\hline V2(Sagar) & $41.00 \mathrm{c}$ & $47.37 \mathrm{~b}$ & 3.24 & $11.14 \mathrm{c}$ \\
\hline V3(NS 632) & $50.32 \mathrm{~b}$ & $57.22 \mathrm{a}$ & 3.50 & $12.54 \mathrm{ab}$ \\
\hline V4(Indra) & $52.18 \mathrm{a}$ & $55.03 \mathrm{a}$ & 3.35 & $13.51 \mathrm{a}$ \\
\hline LSD0.05 & $1.70^{* *}$ & $3.33^{* *}$ & $\mathrm{NS}$ & $1.07 * *$ \\
\hline Levels of nitrogen (kg/ha) (Fb) & & & & \\
\hline N1(200 kg N/ha through chemical fertilizer) & $46.97 \mathrm{~b}$ & $52.05 \mathrm{~b}$ & 3.28 & 12.54 \\
\hline N2(200 kg N/ha through FYM) & $43.66 \mathrm{c}$ & $50.57 \mathrm{~b}$ & 3.33 & 11.94 \\
\hline N3(250 kg N/ha through & & & & 12.62 \\
\hline chemical fertilizer) & $49.26 \mathrm{a}$ & $58.56 \mathrm{a}$ & 3.53 & 11.81 \\
\hline N4(150 kg N/ha through chemical fertilizer) $)$ & $44.75 \mathrm{c}$ & $47.13 \mathrm{c}$ & 3.35 & 12.23 \\
\hline Grand Mean & 46.15 & 52.08 & 3.37 & 0.37 \\
\hline SEM \pm & 0.59 & 1.15 & 0.07 & $\mathrm{NS}$ \\
\hline LSD0.05 & $1.70^{* *}$ & $3.33^{* *}$ & $\mathrm{NS}$ & 10.54 \\
\hline CV\% & 4.43 & 7.69 & 7.79 & \\
\hline
\end{tabular}

Means within the column followed by the same letter for varieties and nitrogen levels are not significant different at $5 \%$ level of significance by DMRT 


\section{Effects of varieties and nitrogen levels on reproductive characteristics}

Table 5. Effects of varieties and nitrogen levels on first date of flowering and fifty percent flowering of sweet pepper at Mangalpur, Chitwan, Nepal (2014/2015)

\begin{tabular}{|l|l|l|}
\hline \multirow{2}{*}{ Treatments } & \multicolumn{2}{c|}{ Days to flowering } \\
\cline { 2 - 3 } \multicolumn{2}{|l|}{ First flowering } & \multicolumn{1}{c|}{ Fifty percent flowering } \\
\hline Varieties(Fa) & $35.00 \mathrm{a}$ & $54.75 \mathrm{a}$ \\
\hline V1(California Wonder) & $23.00 \mathrm{~b}$ & $43.83 \mathrm{~b}$ \\
\hline V2(Sagar) & $23.00 \mathrm{~b}$ & $38.50 \mathrm{c}$ \\
\hline V3(NS 632) & $22.67 \mathrm{~b}$ & $41.00 \mathrm{bc}$ \\
\hline V4(Indra) & $1.08^{* *}$ & $3.03 * *$ \\
\hline LSD0.05 & \multicolumn{2}{|l|}{} \\
\hline Level of nitrogen(kg/ha)(Fb) & 25.17 & 43.83 \\
\hline $\begin{array}{l}\text { N1(200 kg N/ha through } \\
\text { Chemical fertilizer) }\end{array}$ & 26.17 & 45.00 \\
\hline N2(200 kg N/ha through FYM) & 26.17 & 46.08 \\
\hline $\begin{array}{l}\text { N3(250 kg N/ha through } \\
\text { Chemical fertilizer) }\end{array}$ & 26.17 & 43.17 \\
\hline $\begin{array}{l}\text { N4(150 kg N/ha through } \\
\text { Chemical fertilizer) }\end{array}$ & 25.92 & 44.52 \\
\hline Grand Mean & 0.37 & 1.05 \\
\hline SEM \pm & $\mathrm{NS}$ & $\mathrm{NS}$ \\
\hline LSD0.05 & 5.01 & 8.19 \\
\hline CV\% & & \\
\hline
\end{tabular}

Means within the column followed by the same letter for varieties and nitrogen levels are not significant different at $5 \%$ level of significance by DMRT

There was significant difference among the varieties on Days to first flowering of the crop. California Wonder took longer time (35 DAT) than Indra (22.66 DAT) for flower initiation. The highest value was recorded from $200 \mathrm{~kg} \mathrm{~N} /$ ha through FYM followed by $250 \mathrm{~kg} \mathrm{~N} / \mathrm{ha}$ through chemical fertilizer and $150 \mathrm{~kg} \mathrm{~N} / \mathrm{ha}$ through chemical fertilizer (26.167 DAT) and the lowest value was from $200 \mathrm{~kg} \mathrm{~N} / \mathrm{ha}$ (25.16 DAT). The varieties were significantly different in Days to fifty percent flowering. California Wonder took longer time (54.75 DAT) followed by Sagar (43.83 DAT) and Indra (41 DAT). Sagar and Indra were at par while NS 632 took the shortest time (38.5 DAT). The highest value was recorded from $250 \mathrm{~kg} \mathrm{~N} /$ ha through chemical fertilizer (46.08 DAT) and the lowest value was from $150 \mathrm{~kg} \mathrm{~N} /$ ha through chemical fertilizer (43.16 DAT).

Table 6 Effects of varieties and nitrogen levels on fruit parameters of the sweet pepper at Mangalpur, Chitwan,

\begin{tabular}{|c|c|c|c|}
\hline \multicolumn{4}{|c|}{ Nepal $(2014 / 2015)$} \\
\hline \multirow[t]{2}{*}{ Treatments } & \multicolumn{3}{|c|}{ Fruit parameters } \\
\hline & Av. weight & Number of fruits per plant & Total yield $(\mathrm{t} / \mathrm{h})$ \\
\hline & \multicolumn{3}{|c|}{ Varieties $(\mathrm{Fa})$} \\
\hline V1(California Wonder) & $79.93 \mathrm{~d}$ & $6.62 \mathrm{~b}$ & $26.50 \mathrm{~b}$ \\
\hline V2(Sagar) & $82.42 \mathrm{c}$ & $6.30 \mathrm{~b}$ & $25.99 \mathrm{~b}$ \\
\hline V3(NS 632) & $84.34 b$ & $9.26 \mathrm{a}$ & $39.07 \mathrm{a}$ \\
\hline V4(Indra) & $87.59 \mathrm{a}$ & $9.00 \mathrm{a}$ & $39.45 \mathrm{a}$ \\
\hline LSD0.05 & $1.49 * *$ & $0.48 * *$ & $2.16 * *$ \\
\hline \multicolumn{4}{|l|}{ Level of Nitrogen $(\mathrm{Kg} / \mathrm{ha})(\mathrm{Fb})$} \\
\hline $\begin{array}{l}\text { N1(200 kg N/ha through } \\
\text { chemical fertilizer) }\end{array}$ & $83.70 \mathrm{~b}$ & $7.89 b$ & $33.18 b$ \\
\hline
\end{tabular}




\begin{tabular}{|l|l|l|l|}
\hline $\mathrm{N} 2(200 \mathrm{~kg}$ N/ha through FYM) & $83.71 \mathrm{~b}$ & $7.25 \mathrm{c}$ & $30.50 \mathrm{c}$ \\
\hline $\mathrm{N} 3(250 \mathrm{~kg}$ N/ha through chemical fertilizer $)$ & $85.28 \mathrm{a}$ & $8.59 \mathrm{a}$ & $36.69 \mathrm{a}$ \\
\hline $\mathrm{N} 4(150 \mathrm{~kg}$ N/ha through chemical fertilizer $)$ & $81.60 \mathrm{c}$ & $7.46 \mathrm{bc}$ & $30.64 \mathrm{c}$ \\
\hline Grand Mean & 83.57 & 7.80 & 32.75 \\
\hline $\mathrm{SEM} \pm$ & 0.51 & 0.16 & 0.74 \\
\hline LSD0.05 & $1.49^{* *}$ & $0.48^{* *}$ & $2.16^{* *}$ \\
\hline CV\% & 2.15 & 7.45 & 7.93 \\
\hline
\end{tabular}

Means within the column followed by the same letter for varieties and nitrogen levels are not significant different at $5 \%$ level of significance by DMRT

The highest $(87.59 \mathrm{~g})$ Fruit weight was from Indra followed by NS 632 and Sagar but the lowest (79.93 g) was from California wonder. The highest $(85.28 \mathrm{~g})$ fruit weight was from $250 \mathrm{~kg} \mathrm{~N} /$ ha through chemical fertilizer followed by $200 \mathrm{~kg} \mathrm{~N} / \mathrm{ha}$ through chemical fertilizer. Application of $200 \mathrm{~kg} \mathrm{~N} /$ ha through FYM was at par with $200 \mathrm{~kg} \mathrm{~N} /$ ha through chemical fertilizer. The lowest (81.6 g) fruit weight was from $150 \mathrm{Kg} \mathrm{N} / \mathrm{ha}$ through chemical fertilizer.

The highest Number of fruit per plant (9.26) was recorded from NS 632 and it was at par with Indra, but the lowest value (6.30) was from Sagar, which was at par with California Wonder. The highest Number of fruits / plant (8.58) was recorded from the application of $250 \mathrm{~kg} \mathrm{~N} / \mathrm{ha}$ through chemical fertilizer followed by $200 \mathrm{~kg} \mathrm{~N} / \mathrm{ha}$ and $150 \mathrm{~kg} \mathrm{~N} /$ ha through chemical fertilizer. The lowest Number of fruits/plant (7.24) was recorded from the application of $200 \mathrm{~kg} \mathrm{~N} / \mathrm{ha}$ through FYM.

The highest Fruit yield (39.45 t/ha) was recorded from Indra which was at par with NS 632 and the lowest value (25.99 $\mathrm{t} / \mathrm{ha}$ ) was from Sagar which was at par with the California wonder. The highest Fruit yield (36.69 t/ha) was recorded from the application of 250 $\mathrm{kg} \mathrm{N} /$ ha through chemical fertilizer followed by 200 $\mathrm{kg} \mathrm{N} /$ ha through chemical fertilizers and the lowest Fruit yield (30.5 t/ha) was obtained from $200 \mathrm{~kg} \mathrm{~N} / \mathrm{ha}$ through FYM which was at par with the $150 \mathrm{~kg} \mathrm{~N} / \mathrm{ha}$ through chemical fertilizer.

\section{Interaction effects of varieties and nitrogen levels on the Fruit weight and Number of fruits per plant}

Interaction effects of varieties and nitrogen levels on the Fruit weight and the Number of fruit per plant were nonsignificant (Table 7 and 8 ).

Table 4. Effects of varieties and nitrogen levels on plant height at different growth stages of sweet pepper at Mangalpur, Chitwan (2014/2015)

\begin{tabular}{|c|c|c|c|c|}
\hline \multirow[t]{2}{*}{ Treatments } & \multicolumn{4}{|c|}{ Levels of nitrogen } \\
\hline & N1 & N2 & N3 & $\mathrm{N} 4$ \\
\hline V1 & 79.72 & 79.39 & 82.59 & 78.04 \\
\hline V2 & 82.63 & 83.36 & 84.4 & 79.3 \\
\hline V3 & 84.45 & 84.99 & 85.38 & 82.54 \\
\hline V4 & 87.99 & 87.09 & 88.74 & 86.54 \\
\hline Grand Mean & \multicolumn{4}{|c|}{83.57} \\
\hline $\mathrm{SEM} \pm$ & \multicolumn{4}{|c|}{1.03} \\
\hline LSD0.05 & \multicolumn{4}{|c|}{ NS } \\
\hline CV\% & \multicolumn{4}{|c|}{2.15} \\
\hline
\end{tabular}

Means within the column followed by the same letter for varieties and nitrogen levels are not significant different at $5 \%$ level of significance by DMRT 
$\mathrm{V} 1=$ California Wonder, $\mathrm{V} 2=$ Sagar, $\mathrm{V} 3=\mathrm{NS} 632$, $\mathrm{V} 4=$ Indra, $\mathrm{N} 1=200 \mathrm{~kg} \mathrm{~N} / \mathrm{ha}$ through chemical fertilizer, N2= $200 \mathrm{~kg} \mathrm{~N} /$ ha through FYM, N3=250 kg $\mathrm{N} /$ ha through chemical fertilizer and N4=150 kg N/ha through chemical fertilizer
$\mathrm{V} 1=$ California Wonder, V2=Sagar, V3= NS 632, $\mathrm{V} 4=$ Indra, $\mathrm{N} 1=200 \mathrm{~kg} \mathrm{~N} / \mathrm{ha}$ through chemical fertilizer, N2= $200 \mathrm{~kg} \mathrm{~N} /$ ha through FYM, N3=250 kg $\mathrm{N} /$ ha through chemical fertilizer and N4 $=150 \mathrm{~kg} \mathrm{~N} / \mathrm{ha}$ through chemical fertilizer

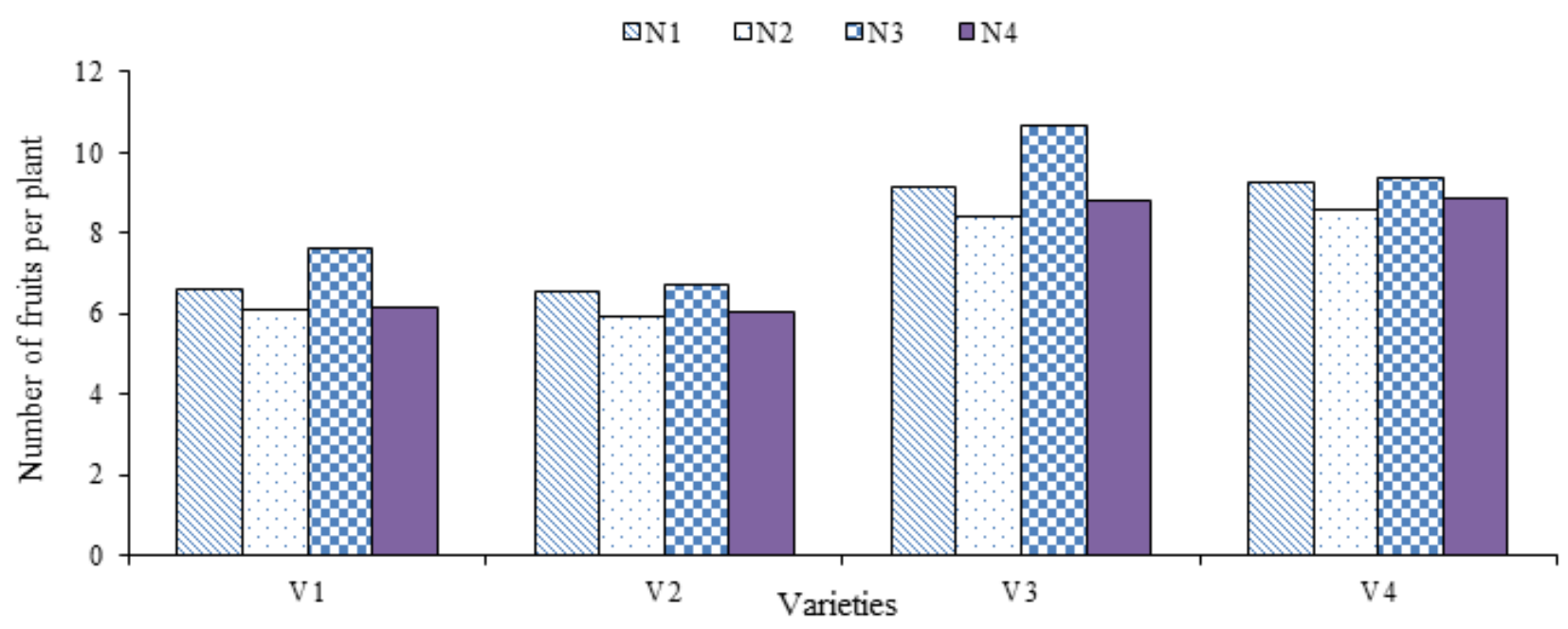

Figure 1. Interaction effects of varieties and nitrogen levels on Number of fruits per plant of sweet pepper at Mangalpur, Chitwan, Nepal (2014/2015)

\section{Interaction effects of varieties and nitrogen levels on Fruit yield}

Interaction effects of varieties and nitrogen levels on fruit yield were non-significant (Fig. 2).
$\mathrm{V} 1=$ California Wonder, V2=Sagar, V3= NS 632, $\mathrm{V} 4=$ Indra, $\mathrm{N} 1=200 \mathrm{~kg} \mathrm{~N} / \mathrm{ha}$ through chemical fertilizer, N2= $200 \mathrm{~kg} \mathrm{~N} / \mathrm{ha}$ through FYM, N3=250 kg $\mathrm{N} /$ ha through chemical fertilizer and N4=150 kg N/ha through chemical fertilizer

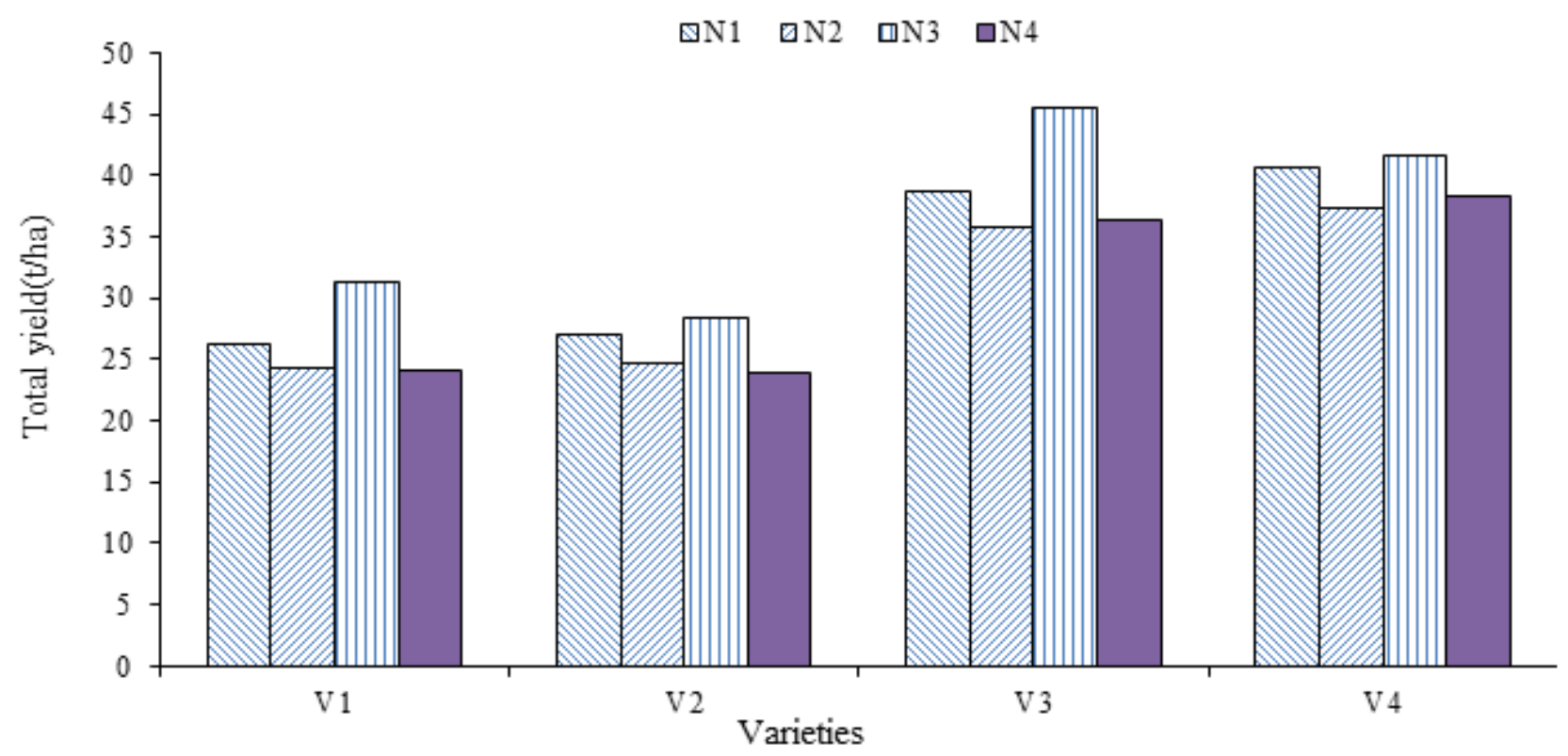

Figure 2.Interaction effects of varieties and nitrogen levels on sweet pepper Fruit yield at Mangalpur, Chitwan, Nepal (2014/2015) 


\section{Discussion}

Plant height is a desirable character which contributes to the increment of plant canopy and biomass. The variations in plant height among varieties were most probably being attributed to their inherited traits or the growing environment. The hybrid varieties gained more height as compared to other open pollinated varieties (Nagre et al., 2013; Shrestha et al., 2013). With the higher rates of nitrogen the plant height was recorded taller than the application of lower level of nitrogen. A higher dose of nitrogen increased plant height (Bar et al., 2001; Bowen \& Frey, 2002; Pervez et al., 2004). Nitrogen increases the vegetative growth of the plants (Baloch, Chachar, \& Tareen,. 2008); thus, it increased with the increment in nitrogen level.

Number of leaves per plant influences the fruit production. The more the vegetative growth, greater will be the process of photosynthesis, ultimately resulting into increased number of fruits per plant. The variations in leaf number among varieties may be due to the genetic makeup of the varieties or due to the agro-ecological variations in which the varieties were evaluated. Higher vegetative growth and more number of leaves per plant in hybrid Indra was also recorded by Nagre et al. (2013). Nitrogen fertilization increased number of leaves that was in agreement with the findings of Ayodele (2002) and Boroujerdnia \& Alemzadeh (2007). The results were also to some extent in agreement with the findings of Roy chaudhury, Chatterjee \& Mitra (1995) that maximum number of leaves per plant was obtained from higher dose of nitrogen applications.

Hybrid varieties produced higher number of branches per plant. Higher vegetative growth was recorded from Indra variety than others, which was consistent findings by several researchers (Nagre et al., 2013 and Swamy et al., 2014). Generally, the differences in branching of pepper plants might be due to genetic variations existed or due to favorable influence of organic and inorganic nutrients present in the soils or the growing environment. Khan et al. (2010) reported that number of branches increased with the increasing nitrogen rate. Nitrogen has a significant effect on number of branches per plant as it activated vegetative growth.

Earliness or lateness in the days to $50 \%$ flowering might have been due to their inherited characters, early acclimatization to the growing area to enhance their growth and developments and/ or due to the transplanting disturbance. Hybrid variety showed early bearing habit as compared to other open pollinated varieties. Baker (1989) reported that the hybrid Indra had comparatively early flower initiation and early first harvest. There was an early flowering from the low nitrogen application rate as compared to high nitrogen rates. Shrivastava (1996) reported that 50\% flowering was delayed with higher dose of nitrogen.

The variations in fruit weight, length and diameter of sweet pepper could be due to the difference in inherited characteristics of varieties and or due to environmental conditions of the growing areas (Sundaram, 1992; Aruna \& Sudagar, 2010). Higher values of fruit length, width and wall thickness contributed to maximum average fruit weight in the hybrids Indra and NS-280 as reported by Swami (2015). Fruit size is increased with the increasing nitrogen rates. Qawasmi et al. (1999) also reported that fruit size was smaller when no $\mathrm{N}$ was applied. Bowen \& Frey (2002) reported that large fruit size was the main factor contributing to higher fruit yield and also reported that increasing the rate of nitrogen fertilizers increased the average fruit weight and volume of pepper.

The hybrid varieties produced more number of fruits than traditional OP varieties. As the number of primary, secondary and tertiary branches increase, there could be a possibility of increasing the number of fruit producing buds. That the fruit production of hybrid varieties was more than the conventional varieties was also supported by Arya (1999) as hybrid varieties had higher potential in terms of yield, uniformity, early maturity, tolerance to biotic and abiotic stresses and better quality.

Availability of soil $\mathrm{N}$ is the most important factor in limiting the yield in organic systems, though mineral $\mathrm{N}$ levels varied by crop, farming system and the amount and source of $\mathrm{N}$ fertilization (Poudel et al., 2002).

Lower yields of sweet pepper with organic manures application may have been associated with the less readily available nutrients as nutrient cycling processes (Harris et al., 1994; Reider et al., 2000) and slower release rates of organic materials (Liebhardt et al., 1989; MacRae et al., 1993). Russo and Taylor (2006) reported that bell pepper yield in the transition to organic production was lower than in the conventional production system. 
Roychaudhury et al. (1995) reported that the number of fruit per plant increased with increasing nitrogen applications. Variation in yield between varieties is due to the genetic variations between the varieties. The increase in total fruit yield could be due to variation in plant height, as well as formation of more primary, secondary and tertiary branches per plant that increased potential of fruit bearing buds and also leaf area that maximized photosynthetic capacity and assimilate partitioning to the fruits. Fertilizer is one of the major factors of crop production and nitrogen is a nutrient essential for good growth and development of plants (Khan et al. 2010). Khan et al. (2010) also reported that optimum dose of $\mathrm{N}$ fertilizer increased proper growth and development and maximized the yield of sweet pepper. Sharma \& Peshin (1994) also stated about the promotive effects of nitrogen application on fruit yield of capsicum.

\section{Conclusion}

The yield and yield attributing characters differed with the varieties. The cultivation of hybrids over the OP was very effective. The hybrids Indra and NS 632 were superior to Sagar and California Wonder varieties. Maximum weight (87.59 g) of Capsicum fruits was obtained from Indra with application of $250 \mathrm{~kg} \mathrm{~N} / \mathrm{ha}$ through chemical fertilizer. Maximum number of fruits per plant (9.25) was recorded from NS 632. Maximum total yield (39.45 t/ha) was from Indra. More yield (36.69 t/ha) was recorded from $250 \mathrm{~kg} \mathrm{~N} / \mathrm{ha}$ through chemical fertilizer and lower yield (30.50 t/ha) from $200 \mathrm{~kg} \mathrm{~N} /$ ha through FYM.

The productivity of pepper is highly responsive to $\mathrm{N}$ fertilizer. The source and level of nitrogen is very important in determining the yield and quality of capsicum. Application of FYM alone produced lower yield as compared to chemical source of nitrogen. It might be due to slower release of nutrients from FYM. The capacity of producing yield varies with the variety, level of nutrients and soil types. Thus, it can be concluded that hybrid Capsicum cultivation with optimum dose of fertilizer in autumn will be profitable in Chitwan.

\section{Acknowledgements}

Authors are grateful to Directorate of Research and Extension of Agriculture and Forestry University (AFU) for providing financial supports and kind cooperation to carry out the experiments.

\section{References}

Aruna, P. \& Sudagar, I. P. (2010). Evaluation of capsicum varieties under poly house conditions. Asian Journal of Horticulture, 4(2), 336-337.

Arya, P. S. (1999). Vegetable breeding and seed production. Kalyani Publishers, Ranjinder Nagar, Ludhiana, India.

Ayodele, V. I. (2002). Influence of nitrogen fertilisation on yield of Amaranthus species. Journal of Acta Horticulture, 571, 89-95.

Baker, J. C. (1989). The effect of air humidity on flowering, fruit set and fruit growth of glass house sweet pepper (Capsicum annuum L.). Scientia Hort., 40, 1-8.

Baloch, Q. B., Chachar, Q. I. \& Tareen, M. N. (2008). Effect of foliar application of macro and micro nutrients on production of green chilies (Capsicum annuum L.). J Agri Tech, 4,177-184.

Bar-Tal, A., Aloni, B., Karin, L. \& Rosenberg, R. (2001). Nitrogen nutrition of greenhouse pepper: Effects of nitrogen concentration and NO3:NH4 ratio on growth, transpiration, and nutrient uptake. J. Hort. Sci., 36, 1525-1529.

Bokhtiar, S. M., Paul, G. C. \& Alam, K. M. (2008). Effects of organic and inorganic fertilizer on growth, yield, and juice quality and residual effects on ratoon crops of sugarcane. Journal of Plant Nutrition 31(10), 1832 - 1843.

Boroujerdnia, M., \& Alemzadeh A. N. (2007). Effect of different levels of nitrogen fertilizer and cultivars on growth, yield and yield components of romaine lettuce (Lactuca sativa L.). Middle Eastern and Russian Journal of Plant Science and Biotechnology, 1, 47-53.

Bowen, P. \& Frey, B. (2002). Response of plasticulture bell pepper to staking, irrigation frequency and fertigated nitrogen rate. Journal of Horticultural Science, 37, 95-100.

Deore, G. B., Limaye, A. S., Shinde, B. M. \& Laware, S. L.(2010). Effect of novel organic liquid fertilizer on growth and yield in chilli (Capsicum annuum L.).Asian Journal of Biological Science. pp. 15-19.

Devlin, R. M. (1972). Plant Physiology. Affiliated East West Press Ltd., New Delhi.

Gupta, M. K. (2003). Performance of chilli (Capsicum annuum L.) genotypes under Tarai condition of Uttranchal (Master thesis, G. B. Pant university of Agriculture and Technology, Pantnagar, India). 
Harris, G. H., Hesterman, O. B., Paul, E. A., Peters, S. E. \& Janke, R. R. (1994). Fate of legume and fertilizer nitrogen-15 in a long-term cropping experiment. Agronomy Journal, 86, 910-915.

Khan, M. S. I., Roy, S.S. \& Pall, K. K. (2010). Nitrogen and phosphorus efficiency on the growth and yield attributes of Capsicum. Academic Journal of Plant Sciences, 3 (2), 71-78pp, 2010.

Liebhardt, W. C., Andrews, R. W., Culik, M. N., Harwood, R. R., Janke, R. R., Radke, J. K. \& Rieger-Schwartz, S. L. (1989). Crop production during conversion from conventional to lowinput methods. Agronomy Journal, 81, 150-159.

MacRae, R. J., Hill, S. B., Mehuys, G. R. \& Henning, J. (1993). Farm-scale agronomic and economic conversion from conventional to sustainable agriculture. Advances in Agronomy, 43, 155-198.

MoAD(2013). Statistical information on Nepalese Agriculture 2012/13. Ministry of Agriculture Development. Agri-Business Promotion and Statistics Division (ABPSD), Kathmandu, Nepal. Available at: http//moad.gov.np/ yearbook/yearbook 2013 Whole pdf.

MOAD. (2014). Statistical information on Nepalese Agriculture 2013/2014. Ministry of Agriculture Development. Government of Nepal. Kathmandu.

Nagre, P. K., Gurav, S. B., Katwate, S. M. \& Raju, S. S. V. (2013). Development of sustainable and economically viable greenhouse production technology for capsicum in plains. Int. J. Agrl.Sc \& Vet.Med. Vol. 1.

Pervez, M. A., Ayub, C. M., Bashart, A., Nave, A. V. \& Nasir, M. (2004). Effect of nitrogen levels and spacing on growth and yield of radish (Raphanus sativus L.). International Journal of Agriculture and Biology, 6, 504-506.

Poudel, D. D., Horwarth, W. R., Lanini, W. T., Temple, S. R. \& vanBruggen, A. H. C. (2002). Comparison of soil $\mathrm{N}$ availability and leaching potential, crop yields and weeds in organic, low-input and conventional farming systems in northern California. Agric Eco Environ., 90, 125-137.

Qawasmi, W., Munir, J. M., Najim, H. \& Remon, Q. (1999). Response of bell pepper grown inside plastic houses to nitrogen fertigation. J. Commun. Soil Sci. Plant Anal., 30(17), 2499-2509.

Rani, P. U. (1996). Evaluation of chilli (Capsicum annuum L.) germplasm and its utility in breeding for higher yield and better quality. Maysore
Journal of Agricultural Sciences, 30, 343-348.

Reider, C., Herdman, W., Drinkwater, L. E. \& Janke, R. (2000). Yields and nutrient budgets under composts, raw dairy manure, and mineral fertilizer. Compost Science and Utilization, 8, 328-339.

Roychaudhury, A., Chatterjee, R. \& Mitra, S. K. (1995). Effect of different doses of nitrogen, phosphorus, potassium, magnesium, calcium and iron on growth and development in chilli. Department of Horticulture Kalyani West Bengal India, 13, 96-99, 1990. (CAB. Abstract. 1993-7/95).

Russo, V. M. \& Taylor, M. J. (2006). Soil amendments in transition to organic vegetable production with comparison to conventional methods: Yields and economics. HortScience.,41, 1576-1583.

Sharma, R. C. \& Upadhaya, N. C. (1993). Nitrogen nutrition of potato. In: K. L. Chadha \& J. S. Grewal, (Eds), Advances in horticulture 7 (Pp. 231-259), Malhotra Publishing House, New Delhi.

Sharma, S. K. \& Peshin, S. N. (1994). Influences of nitrogen nutrition and spacing on plant growth fruits and seed yield of sweet pepper. Indian J. of Hort. 51, 100-105.

Shrestha, D., Srivastava, A., Shakya, S. M., Khadka, J., \& Acharya, B. S. (2013). Use of compost supplemented human urine in sweet pepper (Capsicum annuum L.) production. Scientia Horticulturae, 153, 8-12.

Shrivastava, A. K. (1996). Effect of fertilizer levels and spacings on flowering, fruit set and yield of sweet pepper (Capsicum annum var. grossum L.) cv.Hybrid Bharat. Department of Floriculture and Olericulture, College of Agriculture, Jawaharlal Nehru Krishi Vishwa Vidyalya, Jabalpur - 482004, India. Advances in Plant Sci., 9(2), 171-175.

Sundarm, V. (1992). Evaluation ofF3 and F4 generations for genetic enhancement yield in sweet pepper (Capsicum annuum L.) M.Sc. (Hort.) Thesis, TNAU, Coimbatore (T.N).

Swamy G, N. (2015). Evaluation of certain varieties and hybrids of capsicum for quality attributes under shade net. Journal of Horticulture, 2(01), 10-12. http://doi.org/10.4172/2376-0354.1000124

Swamy, G. N., Srinivasulu, B., Madhumathi, C., Thirupal, D., Babu, M. R. V., Susmitha, P., \& Kendra, K. V. (2014). Assessment of capsicum varieties and hybrids for qualitative traits under shade net.Plant Archives (14) 2, 1051-1054. 